\title{
原形質膜に存在する液胞型 $\mathrm{H}^{+}$-ATPase (V-ATPase) の機能
}

\section{細胞のpH制御を通して神経伝達, 骨の消化など種々の生理現象に関与}

$\mathrm{H}^{+}$を輸送するATPase は大別して 3 種に分けること ができる.このうちの 1 種, 液胞型 $\mathrm{H}^{+}$-輸送性 ATPase (V-ATPase) は, エンドソームやリソゾームのような真 核細胞の細胞内膜系 (central vacuolar systems) に属す るオルガネラに存在しており, 内部を酸性に維持してい る. この膜を介する酸性 $\mathrm{pH}$ あるいは $\mathrm{H}^{+}$の電気化学 的ポテンシャル差 ( $\mathrm{pH}$ 勾配と膜電位) が内膜系オルガ ネラのもつ様々な機能に必須であることが明らかにされ つつある(1,2). たとえば, 神経末端に存在するシナプス 小胞は高濃度の神経伝達物質を内部に蓄積している.こ の蓄積は, V-ATPase により形成された $\mathrm{H}^{+}$の電気化学 的ポテンシャル差を駆動力として, 伝達物質が能動的に 輸送された結果である. 神経遮断薬や局所麻酔剤もこの $\mathrm{pH}$ 勾配を利用してシナプス小胞内に数百倍に濃縮され る(3). 神経遮断薬はシナプス後膜に存在するレセプター に結合し神経伝達を遮断するわけであるから，遮断薬の 小胞内への濃縮は効率的なレセプターへの結合を促進し ていると考学られる. 抗癌剤のダウノマインンがリソゾ 一ムに蓄積する現象は癌細胞の薬剤耐性機構を考える上 で重要であるが，この蓄積も V-ATPase により形成さ れたりソゾーム内部の酸性 $\mathrm{pH}$ が駆動力となってい る(4). したがって, V-ATPase は, 薬物の作用機構を考 える上で重要かつ新しいポイントであろう.

V-ATPase の存在場所に関する知見が増えるにつれ， 原形質膜にも V-ATPase がきわめて多量に存在してい る例が見いだされた。この場合, V-ATPase の触媒部位 (ATPase 活性を持つ部位) は細胞質側に向いて括り, $\mathrm{H}^{+}$は細胞外へ排出される. 本稿では, 原形質膜に存在 する V-ATPase の生理機能について紹介する.

破骨細胞は，骨を消化し吸収することにより骨の新生 を促している. 骨の消化に $\mathrm{H}^{+}$ポンプが関係しているこ とは以前から指摘されていたが, 生化学および組織化学 的な解析から,この $\mathrm{H}^{+}$ポンプは V-ATPase に他なら ないことが示された(5).すなわら,この細胞の波状縁 (ruffled border) に存在する V-ATPase が骨の消化吸 収部位であるハウシップ窩に $\mathrm{H}^{+}$を放出し, その部分を 酸性（およそ $\mathrm{pH} 4.0 ）$ にする.この酸性 $\mathrm{pH}$ により $\mathrm{Ca}^{2+}$ やリン酸などのミネラルが骨組織より遊離しやす くなると同時に，細胞より排出されたりソゾーム系の蛋 白質分解酵素が活性化され，骨組織に含まれるコラーゲ ンなどの蛋白質の分解が促進される. 実際, V-ATPase を阻害すると骨の消化も阻害される.V-ATPase 活性の 六進は骨消化の増大に結びつく可能性があり, V-ATPase は骨粗鬆症の発症要因の一つとして注目されてい る.

腎臓の尿細管にも V-ATPase が存在する.この VATPase $は$ intercalated cell (A型) の apical 側に存在 しており, $\mathrm{Na}^{+} / \mathrm{H}^{+}$交換輸送体とともに $\mathrm{H}^{+}$を原尿中に 排出している(6). この $\mathrm{H}^{+}$は限外濾過された重炭酸イオ ンの再吸収に必要である. 尿細管には重炭酸イオンを尿 中に排出する intercalated cell (B型) も存在している. この細胞には V-ATPase が basal 側に存在しており, $\mathrm{A}$ 型細胞とは逆向きのイオン輸送を行なっている.この ように, V-ATPase は尿細管に打いて, 体液中の酸, 塩 基のバランスを維持するために高度に組織化されてい る. V-ATPase と $\mathrm{Na}^{+} / \mathrm{H}^{+}$交換輸送体の組み合わせに よる細胞質 $\mathrm{pH}$ の制御は, マクロファージにおいても見 られ(7)，少なくとも動物細胞に打いては普遍性がある可 能性がある。

V-ATPase のサブニニット組成は酵母からヒトに至 るまでほぼ等しく, 主要なサブユニットの一次構造もよ く保存されている. しかしながら，原形質膜に存在して いる V-ATPase には内膜系の酵素とは異なった点も見 いだざれている. intercalated cell に存在している VATPase は, 脳や肝蔵などで発現しているものと構造的 に少し異なっている.すなわら、アミノ末端とカルボキ シル末端の一次構造が異なるアイソフォームがサブュニ ットBとEに見いだされている. 酵素学的にも，至適 
$\mathrm{pH}$ や阻害剂に対する感受性が通常のV-ATPase とは 異なっている(6). 破骨細胞の V-ATPase においても類 似のアイソフォームが見いだされている.この ATPase で特徵的なことはバナジン酸に対する感受性がきわわて 高いことである(8). 通常, バナジン酸はリン酸化中間体 を形成する $\mathrm{P}$ 型の $\mathrm{H}^{+}-\mathrm{ATPase}$ の阻害剂と考えられて いるが，破骨細胞の ATPase の感受性はこれに匹敵す るものである.こうした特徴的な原形質膜の V-ATPase の性質は, V-ATPase の構造と機能を解明するらえで有 用であろう。どのような機構により V-ATPase が特定 の原形質膜へ輸送されるのか，ターゲッティングも興味 深い問題である.

さて，尿は尿管を経て，最終的に膀胱内に貯溜する. この間，尿の $\mathrm{pH}$ はいったん中性付近まで上昇するが， 筆者らは膀胱内で再度酸性化されることを見いだし た ${ }^{(9)}$. 膀脱内に V-ATPase 阻害剂であるバフィロマイ シンやュンカナマイシンを注入すると, 尿の酸性化が阻 害され， $\mathrm{pH}$ は中性付近まで上昇した，したがって，膀 胱内の尿の酸性化も V-ATPase により行なわれている と考光られる. 免疫組織化学的な解析から, V-ATPase は上皮細胞の apical 側の原形質膜, すなわち尿之直接 接する部分に存在していることが判明した.さて，膀胱 内部を V-ATPase 阻害剂で処理すると同時に大腸菌を 注入すると，膀脱上皮細胞に菌が付着しやすくなった． 尿が酸性化しているとこうした細菌の付着はまったく見 られない. 細菌の付着は細胞の細菌感染の最初のステッ プであるため，この結果は，V-ATPase による尿の酸性 化は細菌の感染防御の一端を担っていることを示唆して いる.くだけて言壳ば, V-ATPase が膀胱炎を防いでい る可能性があるわけである. 興味深いことに, 膀胱内の 尿の $\mathrm{pH}$ は日周期性を示した. これは V-ATPase 活性 ないし $\mathrm{H}^{+}$輸送に伴う二次的なアニオン輸送が概日リズ ムをもつことを示した初めての例であり，その機構の解 明が待たれる。

昆虫に拈いても，V-ATPase が原形質膜に豊富に存在 する例が知られている，昆虫の消化管におけるアミノ酸 やイオンの吸収は細菌や哺乳類の場合と異なり, 原形質 膜を介する $\mathrm{K}^{+}$の濃度勾配が駆動力となっている.この $\mathrm{K}^{+}$の濃度勾配を作る一次ポンプとして V-ATPase が
働いていることが明らかにされた ${ }^{(10)}$ 。すなわら，中腸腺 の杯状細胞 (goblet cell) の apical 側の原形質膜には V-ATPase が存在し, 細胞外 (管腔内) へ $\mathrm{H}^{+}$を放出す る. 同じ原形質膜に存在する $\mathrm{K}^{+} / \mathrm{H}^{+}$交換輸送体が $\mathrm{H}^{+}$. と $\mathrm{K}^{+}$を交換し, 結果的に $\mathrm{K}^{+}$の濃度勾配が形成され る. 同一膜上に V-ATPase と $\mathrm{K}^{+} / \mathrm{H}^{+}$交換輸送体が存 在している例は，すでにリソゾームや副甲状腺のセロト ニン顆粒などで知られているが(11)，昆虫に拈いてはより 一般的らしい. 基本的に同じェネルギー変換系が, マル ピーギ管や触覚基部などでも見いだされだ(12). 特に, 触 覚基部の助細胞に括いては, 触覚に括いて感知された刺 激が，膜内外に形成された $\mathrm{K}^{+}$の濃度勾配の変化 $\left(\mathrm{K}^{+}\right.$ 電流）として脳に伝えられるらしい，これは，V-ATPase が神経における情報伝達に関与するシナプス小胞以 外の例であり, 類似の機構が䄃椎動物の内耳などにも存 在している可能性がある.

V-ATPase が存在する所には必ず $\mathrm{H}^{+}$と共役した細 胞機能が存在している. 今後も V-ATPase が存在する 部位を一つ一つ同定していくことで, 現在想像もできな い細胞機能が明らかになるに違いない。

1) 森山芳則 : 生化学, 65, 413 (1993).

2) Y.Moriyama, M. Maeda \& M.Futai : J. Exp. Biol., 172, 92 (1992).

3) Y. Moriyama, H. -L. Tsu \& M. Futai : Arch. Biochem. Biophys., 305, 278 (1993).

4) Y.Moriyama, T. Manabe, T. Yoshimori, Y. Tashiro \& M. Futai : J. Biochem., in press (1993).

5) H. K. Vaananen, E.-K. Karhukorpi, K. Sundquist, B. Wallmark, I. Roininen, T. Hentunen, J. Tuukkanen \& P. Lakkakorpi : J. Cell Biol., 111, 1305 (1990).

6) S. L. Gluck : J. Bioenerg. Biomembr., 24, 351 (1992).

7) C. J. Swallow, S. Grinstein \& O.D. Rotstein : J. Biol. Chem., 265, 7645 (1990).

8) D. Chatterjee, M. Chakraborty, 'M. Leit, L. Neff, S. Jamsa-Kellokumpu, S. Fuch \& R. Baron : Proc. Natl. Acad. Sci. USA, 80, 6853 (1992).

9) K. Tomochika, M.Mori, H. Kumon, Y. Kanemasa, K. Oguma, Y. Moriyama \& M. Futai : 投稿中 (1993).

10) H. Wieczorek, M. Putzenlechner, W. Zeiske \& U. Klein : J. Biol. Chem., 266, 15340 (1991).

11) Y. Moriyama : Biochem. Biophys. Res. Commun., 156, 211 (1988).

12) U. Klein \& B.Zimmerman : Cell Tissue Res., 266, 265 (1991).

(森山芳則, 大阪大学産業科学研究所) 


\section{葉緑体局在型グルタミン合成䣼素は光傷害を回避する 役割をになう}

\section{見えてきた光呼吸系の意義}

葉緑体に局在するグルタミン合成酵素 (GS 2) は, 硝 酸還元作用で生成したアンモニアをグルタミンに同化す るとともに, 光呼吸経路で生成するアンモニアを再同化 する代謝的機能をるつことは知られていた，ところが， 植物の葉を強光で照射した条件下で光呼吸経路を止める と, 比較的すみやかに光傷害を起こし, 光合成装置が破 壞されてしまうこと，光傷害を避ける機能をもつ光呼吸 系の中で, 特に GS 2 が重要な役割をもつことが明らか となってきた。

強光下での光傷害には $\mathrm{CO}_{2}$ の存在の有無が大きく影 響する.たと党ば，強光 (真夏の直射日光とほ注同じ 10 万 lux）のもとで $\mathrm{CO}_{2}$ の供給を断つと，タバコ葉は 24 時間のうちに褐変化する. GS の特異的阻害剤 MSO (methionine sulfoximine) を与えて光呼吸系の流れを止 めると, 褐変化はさらに速まり, 数時間でクロロフィル が完全に分解されてしまう，ところが $\mathrm{CO}_{2}$ が十分供給 された条件下では, MSO 存在下でも強光による光傷害 （クロロフィルの退色）は 24 時間後も観察されない. 光 合成装置は，その産物である ATP，NADPH を消費・ 酸化し， $\mathrm{ADP} ， \mathrm{NADP}^{+}$を再生産する $\mathrm{CO}_{2}$ が存在すれ ば，相当の強光下でも機能するのに対して， $\mathrm{CO}_{2}$ が存在 しないときに強光を受けると，著しい損傷を受けるので ある。

$\mathrm{CO}_{2}$ の存在しないときに光照射により光合成活性が すみやが低下することは, 光阻害 (photoinhibition) として早くから知られていだ(1). 強光にょる光阻害で は, 最初に系 2 の反応中心が活性を失い, D 1 タンパク 質が分解を受けることは近年よく研究されている. しか し，系 2 が失活した後な抬強光が続いた場合，どのよう な経過で光合成装置全体の破壊となるかは，まだ明らか ではない，系 2 抢よび系 1 の反応中心が失活し，な抬 光を受けた場合，活性酸素が大量に発生し，それにより 光合成装置が破壊されることは間違いないであるう。葉 緑体内には活性酸素の消去系があることはよく知られて
いる(2)が，そのように大量に発生した活性酸素を消去し

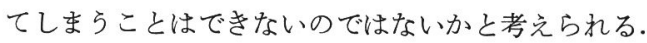

GS 2 以外の光呼吸経路酵素の阻害剤を用いても, 光傷 害は著しく速まること，また強光照射時に $\mathrm{O}_{2}$ 分圧を下 げても光傷害の出現は早まることなどからみて, $\mathrm{CO}_{2}$ の 供給が制限される条件の下では, 光呼吸経路が回転する ことによって，光傷害が起こることを防いでいることは 明らかである. 光呼吸は, せっかく同化した炭水化物を 分解するので，無䭾な代謝であると考兄られたこともあ ったが，光呼吸経路に欠損を持つ変異株のいずれも，通 常の空気中では生存できず, $\mathrm{CO}_{2}$ 濃度を上げるか $\mathrm{O}_{2}$ 濃 度を下げた条件でのみ生育できるといら事実 ${ }^{(3)}$ は，光呼 吸系の重要性をよく示している，光呼吸系では， $\mathrm{O}_{2}$ を 消費し $\mathrm{CO}_{2}$ を放出すること, ATP, NADPH を消費す ることからもわかるように, 光合成の逆反応となってい る.したがって， $\mathrm{CO}_{2}$ の供給が制限される条件の下で， 過剩な光エネルギーが活性酸素の発生へと流れないよう にしていることが光呼吸の生理学的役割である，と規定 してよいのではないか. 活性酸素の消去にもエネルギー が必要であることからも明らかなように，植物が光合成 装置の破壊（ひいては細胞死）を防ぐためにェネルギー を使うのは当然ともい光る.

ところで, 作物の中でカボチャやトマトなどは，比較 的強光に対して強く, $\mathrm{CO}_{2}$ の存在しない条件のもとで強 光照射しても，24 時間後にも光傷害はほとんど現われ ない，ところが MSOを与兄て強光照射すると，やはり 数時間で光傷害を受けるので, これらの作物は光呼吸に よる光傷害回避作用が強い，とい方る．これらの葉には 多量の GS 2 が含まれている。一方，キュウリ，サラダ ナ, ミッバなどは強光照射に弱く, 数時間のうちに褐变 化するが, GS 2 含量は非常に低く, 光呼吸による光傷 害回避作用は注之んど認められない。タバコ、インゲン マメ, エンドウなどは, 光傷害の受けやすさ, GS 2 含量 ともに, カボチャトマトとキュウリ，サラダナ、ミッ 
バとの中間である. エンドウを $\mathrm{CO}_{2}$ 含量を高めて栽培 すると, 光呼吸をする必要がないためか, 通常の空気中 で育てたものと比較して, GS 2 含量が低下する.この よらなェンドウを強光照射すると, 空気中で育てたも のと比較して,より早く光傷害を受けることがわかっ た(4). また, タバコ, エンドウを強光照射すると, 葉組 織内にアンモニアが蓄積してくるので, 光呼吸経路では GS 2 によるアンモニアの同化段階が律速になっている ものと考えられる. そこで, タバュにイネの GS 2 cDNA を遺伝子導入し, GS 2 含量が約 2 倍に増加した形質転 換タバコについて強光照射したところ, 対照区のタバコ より光傷害を起こしにくいことがわかった. 現在, GS 2 含量の低いサラダナやキュウリに GS 2 遺伝子を導入 L, GS 2 含量を高めることを試みている.

光呼吸は, RubisCO (リブロース二リン酸カルボキシ ラーゼ/オキシゲナーゼ）のオキシゲナーゼ作用で生成 するホスホグリコール酸, グリコール酸, グリオキシル 酸が RubisCO の活性を阻害するために，これらを代謝 する経路として発達したものと考えられる. 藻類では, グリコール酸を水中に放出して細胞内に蓄積しないよう にしている. 植物は進化の過程で陸上化する際に気孔を 発達させているが, 乾燥により気孔を閉じると $\mathrm{CO}_{2}$ の 供給が制限されること, 水中よりもはるかに強い光にさ
らされることのために, RubisCO のオキシゲナーゼ作 用によるグリコール酸などの生成は, 陸上に拈ける汪ら が水中よりもはるかに多かったと考光られる。これらの 化合物を効率よく代謝し再利用すると同時に, $\mathrm{CO}_{2}$ の供 給が制限されている条件のもとで, 過剩なエネルギーが 活性酸素の生成へとつながらないように, 細胞内に $\mathrm{CO}_{2}$ を発生させ $\mathrm{O}_{2}$ を消費し, 電子伝達がすみやかに流れる ように $\mathrm{ADP}$ と $\mathrm{NADP}^{+}$とを再生する機能をもつ光呼 吸経路が完成したと考えられる．このように考えると， 光呼吸経路の完成は, 植物の陸上化にとって必須の代謝 系であった，と推定される，光呼吸経路の重要な反応系 を含むぺルオキシゾームがコケ植物以上の陸上植物にの み発達していることは，この推定の妥当性を示唆してい る. 光呼吸系のそのような意義は, $\mathrm{CO}_{2}$ 濃縮機構を特別 にはもたない $\mathrm{C}_{3}$ 植物において，今日でもなお生きてい るはずである.

1) C. B. Osmond : Biochim. Biophys. Acta, 639, 77 (1981).

2) K. Asada \& M. Takahashi : "Photoinhibition", ed. by D. J. Kyle et al., Elsevier Science, Vol.9, 1987, p. 227.

3) D. W. Husic, H.D. Husic \& N.E. Tolbert : CRC Critical Reviews in Plant Sciences, 5, 45 (1987).

4) A. Kozaki \& G. Takeba : Plant Cell Physiol., submitted. (木崎暁子*1, 竹葉 剛*2, *1京都大学農学部, $* 2$ 京都府 立大学生活科学部)

\section{新しいタイプの抗体酵素}

\section{機能性分子用ホストタンパク質としての抗体および抗体L 鎖の利用}

抗体は, その高い抗原結合の特異性により, 生物学の 各分野で幅広く利用されている. 抗体は $\mathrm{H}$ 鎖と L 鎖と呼 ばれるポリペプチド鎖がジスルフィド結合で結ばれた Y 字型構造をしており（図 1), その $\mathrm{N}$ 末端側に 2 個所の抗 原結合部位を有する. 一般に, 抗原に対する抗体の産生 は高分子物質に対してのみ起こるが，低分子化合物であ ってもハプテンとしてポリマーに担持させれば，その八 プテン部分を特異的に認識・結合することのできる抗体 を産生させることができる。

抗体に触媒機能を持たせようといら試みは以前からな されていたが，たとえば，目的の酵素反応における基質 や生成物を抗原として使用しても, 目的の活性を保持す
る抗体を取得することは困難であった，最近の酵素反応 機構解析の進展により, 酵素の活性部位は基質や反応生 成物よりも遷移状態にある反応中間体と安定に結合でき ることが明らかになった点, そしてハイブリドーマセル 法などにより化学的に均一なモノクローナル抗体を取得 できるよらになった点などを背景として，遷移状態類似 のモデル化合物をハプテンとして選択すれば，モノクロ 一ナル抗体に酵素活性を持たせうることが示された ${ }^{(1,2)}$. 今までに認められた触媒活性の例としては, カルボン酸 エステル, 炭酸エステル, アミドの分解, ラクトン化, クライゼン転移， $\beta$ 脱離反応, 酸化還元反応などを触媒 的に加速する抗体が報告されている(3). 抗体が触媒活性 


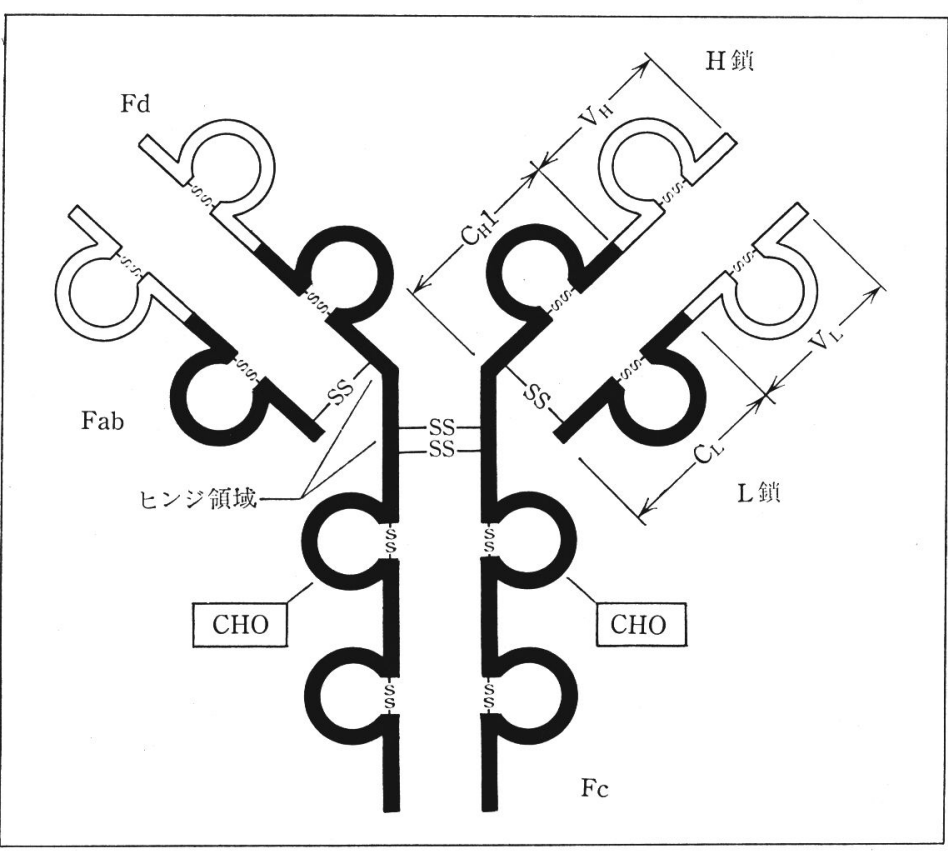

図 1 -抗体 $(\mathrm{IgG})$ の基本構造

-SS-：ジスルフィド結合， $\square$ : 可変領域, $\square$ : 定常領域

を有する場合の利点は, 普通の酵素の場合よりも高い基 質選択性を示すことが多いことで，抗原の選択方法によ っては, 新たな活性を持つ抗体触媒を作り出せる可能性 を秘めていることから, 現在も精力的に研究が進められ ている.さらに, 抗体遺伝子を大腸菌などの培養の容易 な細菌を宿主として組み込み, 生産させれば, 抗体タン パク質といえども容易に供給することが可能となるであ ろう.

筆者らは, 新しいタイプの抗体酵素の作製を試みてい る. カタラーゼやペルオキシダーゼの酵素活性中心で は, 機能性分子のポルフィリンがタンパク質に覆われた 状態をしている事実に着目し, 抗ポルフィリン抗体が, ポルフィリンを包接した状態でペルオキシダーゼ活性を 有するといら仮定を立てて研究を進めてきた．この抗ポ ルフィリン抗体の場合, 抗体が抗原であるポルフィリン と結合している状態ではじめて活性を保持する点で, 他 の抗体酵素とは違ったニニークな特徵を有していると考 它れ, 単なる抗体酵素と異なり,ペルオキシダーゼ類 似活性を持つ機能性分子であるポルフィリンのホスト分 子として抗体を利用しようといら試みである. 現時点で
の進行状況として, (1)ポルフィリン に対するモノクローナル抗体を安定 に生産するハイブリドーマ細胞を取 得した，(2)同抗体がペルオキシダー ゼ活性促進効果を有していることを 確認した，(3)大腸菌を宿主として同 抗体遺伝子をクローニングした, (4) 抗体の L 鎖のみでも抗原に結合し， ペルオキシダーゼ活性を示した，の 4 点について興味ある知見が得られ ている. 以下に, その概略を紹介し よう.

ポルフィリンの 1 種である TCPP (meso-tetrakis (4-carboxypheny1) porphyrin)をハプテン, KLH (keyhole limpets hemocyanin) タンパ ク質をハプテンキャリャーとしてマ ウスを免疫し, 脾蔵細胞と骨髄腫細 胞を融合させて, 最終的には 2 種類 の抗ポルフィリン抗体産生ハイブリドーマ細胞を単離す ることができた.ポルフィリンの示すぺルオキシダーゼ 活性を促進する効果は, 一方の抗体 (03-1) には認めら れたが, るら一方 (13-1) には認められなかった（図 $2)^{(4)}$. 両抗体遗伝子の $\mathrm{Fab}$ 領域を, 大腸菌を宿主と乙 てクローニングし, 塩基配列を決定したところ, 超可变 部領域 (CDR) 飞扮いて両抗体の配列は明らかに異なっ ていた. したがって，03-1 抗体と 13-1 抗体は乞れぞれ ポルフィリンを異なった部位または様式で認識している と考觉れる.

大腸菌の T 7 RNA ポリメラーゼ発現系を用いて, 抗 体の L 鎖および $\mathrm{H}$ 鎖をそれぞれ大量発現させたところ， 菌体内にインクルージョンボディーの形で生産物の蓄積 が認められた、インクルージョンボディーは, 菌体破碎 後の不溶性画分から回収される. そこで, その不溶性タ ンパク質を $6 \mathrm{M}$ 塩酸グアニジンにより可溶化したのち, 透析により再フォールディングさせてタンパク質標品と した. 組換光体の生産する抗ポルフィリン抗体タンパク 質のらち，13-1 ならびに 03-1 抗体の L 鎖単独でもポル フィリンに結合することが酵素免疫法 (ELISA 法) に 


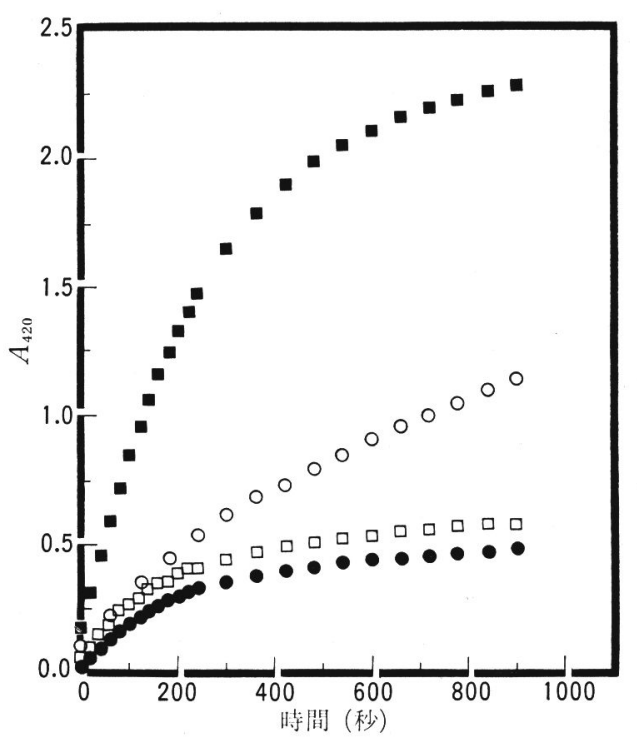

図 2 ロポルフィリン (TCPP) と抗体の複合体形成時における 触媒活性

基質としてピロガロールを用いてペルオキシダーゼ活性を 420 nm に和ける四光度の変化によって測定した. ：TCPP のみ， $\square$ : TCPP と 03-1 抗体 $\mathrm{L}$ 鎖, $\mathrm{O}$ : TCPP と 03-1 抗体 Fab 領域, 口: TCPP と 13-1 抗体 L鎖. 13-1 抗体 Fab 領域の場 合，TCPP のみと差がなかった。

よって明らかになった・今まで， $\mathrm{H}$ 鎖のみでも抗原結合 性を示すといら例はあったが，L鎖のみで結合する例は ないことから，大変興味が持たれる.ささらに、ペルオキ シダーゼ活性の認められた 03-1 抗体由来の L 鎖のみを ポルフィリンに結合させてペルオキシダーゼ活性を測定 した場合に, Fab 領域と同様の効果が認められたことか ら（図 2)，抗体L鎖のみによる抗原との結合，さらには ホスト分子としての機能が確認できた.

塩基配列に基つくくアミノ酸配列から両抗体の可変部領 域の立体構造を, $\mathrm{AbM}$ 抗体三次元構造予測プログラム
(Oxford Molecular 社) により予測し，抗体の抗原結合 部位の構造を推定すると, 03-1 抗体においては, ポルフ ィリンが結合すると考学られる領域には超可変部領域に よって構成される深いクレフトが存在し，その部位にポ ルフィリンが包接されると考えられた. また，13-1 抗体 の L 鎖についても同様の検討を加えたところ, Fab 領域 では活性が認められなかったが，L鎖のみだと非常に強 い活性を示した（図 2)。このことは，H鎖がむしろ活性 発現に対し，立体障害となっていることを予想させる。

現在は, 両抗体および抗体 $\mathrm{L}$ 鎖の解離定数の決定ならび に, 結合様式の解析などを進めている.

抗体は, 抗原の選択によってデザイン可能なタンパク 質分子であることから, タンパク質工学的取り扱いの面 でも他のタンパク質とは異なった独自の特徽を有してい る.そのような背景に基づき，抗体のタンパク質工学 は, 抗体工学という新たな学問分野として成熟しつつあ る. 取り扱いの簡便な大腸菌を宿主としてモノクローナ ル抗体の大量発現がでさるよらになったことは，抗体を 安価に供給できることのみならず，抗体の小型化およ び構造一機能相関の解析においてもますます威力を発揮 するであろう。

1) A. Tramontano, K. D. Janda \& R. A. Lerner : Science, 234, 1556 (1986).

2) S. J. Pollack, J. W. Jacobs \& P. G. Schultz: Science, 234, 1570 (1986).

3) R. A. Lerner, S. J. Benkovic \& P. G. Schultz: Science, 252, 659 (1991).

4) 原田 明: “新生化学実験講座 1. タンパク質 (VII) タンパク 質工学『第6 章 抗体酵素』, 太田隆久他編, 日本生化学会, 東京化学同人, 1993.

（高木昌宏, 今中忠行, 原田 明*, 蒲池幹治*, 大阪大学工学部, *大阪大学理学部)

\section{アカフジツボ・レクチンとバイオミネラリゼーション}

\section{解明進むレクチンの多様な生理機能}

レクチンは糖認識結合タンパク質の総称で, その存在 はあらゆる生物で知られている. 重要な生理機能を担っ ていることには疑問の余地がないが，生物によって起源 を異にすると思われる複数の分子種がすべてレクチンと してまとめて取り扱われてきたため，生理機能として挙 げられた多くの候補を系統的に整理して理解することは
なかなか難しい、たと竞ば, 無脊椎動物リンパ液中のレ クチンは免疫グロブリンに代わって異物認識にあたると する説が有力であるが，生体防御系への関与が実験的に 示されたものは少数で, 多くの無脊椎動物でのレクチン の役割はよくわからない、そこで筆者らは, カルシウム 依存性でCタイプ動物レクチンに分類されるアカフジッ 


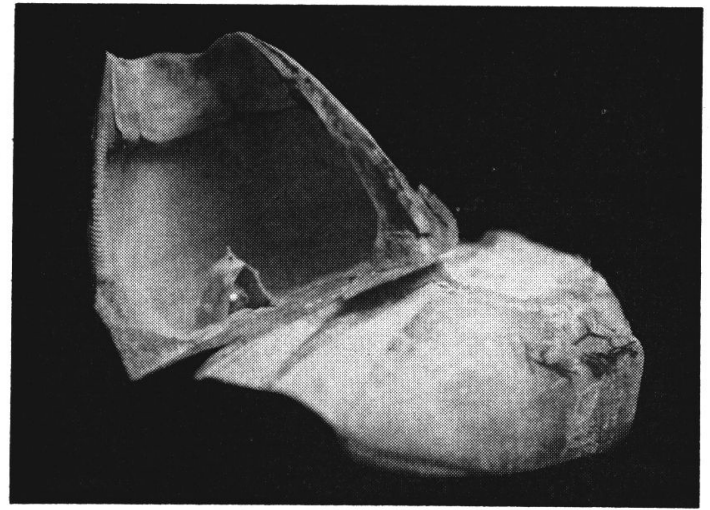

石灰質で被われた鋼球（挿入後 5 週間）

ボ・リンパ液のマルチプル・レクチンに着目し, 化学構 造，活性部位などを明らかにした(1)。さらに，それらの 生理機能について検討を進めた結果, アカフジツボ・レ クチンは生体防御機構ばかりでなく, 殼形成など複数の 生理機能に関与している可能性がでてきた.

マルチプル・レクチン（BRA-1～3）の動態を詳細に 調べたところ, 生体防御との関連のみでは理解し難い現 象が認められた.レクチン量と組成が季節変動するので ある(2). すなわち, 数年間にわたって毎月 $100 〜 150$ 個 体のリンパ液をプールして、レクチン量と組成を調べた ところ，BRA-2（分子量 14 万), BRA-3 (6.4 万) と もに初夏の頃に増加し，冬期に減少することがわかっ た.リンパ液レクチンが委節変動することが明らかにな つた初めての例であろう、レクチン組成をみると，常に BRA-2 が主成分で, BRA-3 がそれに次ぎ, BRA-1 (33 万）は量も少なく, 変動も少ない. 酵素免疫測定法で個 体毎にレクチンの組織別分布を調べたところ，大部分は リンパ液中に存在するが, BRA-2 はその他, 外套膜, 卵巣, ヘモサイトに, BRA-3 は卵巣にもかなりの量が 存在した。また，蔓脚，鰓，筇肉などの組織にも微量の レクチンが認められた．特筆すべきは，リンパ液中のレ クチンが血清タンパク質の $20 \sim 30 \%$ ，個体によっては $60 \%$ 以上にも達することである ${ }^{33}$.

このような量や季節変動を異物認識という生理機能だ けで説明することは難しく、レクチンがもっと根本的な 生命現象に関わっていると考えたほうがよい. その一つ の候補はバイオミネラリゼーション（石灰化）への関与 である. アカフジッボをEDTA で脱灰後, 免疫染色す
ると, 特に石灰化と密接に関与する蔓脚部が強く染色さ れること(2), Cタイプ・レクチンに特徴的なドメインが 萃臓結石タンパク質や軟骨プロテオグリカンなど石灰化 に深く関与する成分にも存在すること年が，このアイデ アのきっかけとなった，差吸収スペクトル法で調べたレ クチンのカルシウム結合定数 $(\mathrm{pH} 8.0)$ は, 骨や歯の可 溶性タンパク質, ホスホフォリンやオステオカルシンと 同程度であった. また，カルシウムとの結合能は $\mathrm{pH}$ に 依存しており，pH 7.0 では結合定数は大きく減少し $た^{(5)}$.

生物におけ方石灰化の機構は個々の生物種に特徵的で あると思われるが，石灰化過程に共通することはミネラ ル沈着に先えじて有機質性の基質（多くの場合，不溶性 タンパク質とカルシウムイオンとの結合性の高い酸性の 可溶性タンパク質の組み合わせからなる）が形成される ことであるという. また，石灰化をコントロールする可 溶性の成分は遊離の状態では石扊化阻害活性を示すが, 不溶性基質に結合した状態では石灰化を促進すると考え られている.たと社, カニでは殼マトリックス中のタ ンパク質成分は遊離の状態では炭酸カルシウムの結晶化 阻害活性を示し, キチン片などに結合させた不溶化の状 態では結晶化を促進することが明らかにされている.こ の結晶化阻害あるいは促進は, 炭酸カルシウム結晶形成 に伴う反応液の $\mathrm{pH}$ 低下で容易に追跡することができ $ろ^{(5)}$.

実際に検討したところ, アカフジツボ・レクチンは positive control としたポリアスパラギン酸ほどではな いが，強い結晶化阻害活性を示した。 最低阻害濃度は $0.3 \mu \mathrm{g} / \mathrm{ml}$ で, リンパ液中に存在するレクチン濃度より はるかに低い。をた，カルボキサミドィチル化してレク チンの糖認識結合ドメインを破壊すると, 血球凝集活性 と同じように結晶化阻害活性もなくなるが，糖認識ドメ インを保持するような断片化では阻害活性も残るので, 結晶化阻害活性と糖認識結合部位とは同じドメインにあ ると考えられる. 一方, アカフジッボの殼マトリックス 中のタンパク質成分も強い結晶化阻害活性を示した.こ のなかにはレクチン抗体と反応する成分があり, 現在, 化学的性状について分析を進めている. 結晶化した炭酸 カルシウム中には反応系に加亲たレクチンの数\%が取り 
込まれるので(5)，マトリックス・タンパク質とレクチン との関係が明らかになれば石灰化への関与が証明される と期待される.

以上まだ状況証拠ばかりであるが，アカフジッボ・ レクチンがそのポリペプチド鎖の修飾や $\mathrm{pH}$ 変化によ り糖やカルシウムとの結合能を変化させるという実験的 観察は, 生体内でも酵素的修飾や局所的な $\mathrm{pH}$ 勾配の形 成によってレクチンの機能が容易に修飾されらることを 示しており, レクチンがカルシウムの輸送・貯蔵や結晶 化などに深く関与するという筆者らの推測を支持してい る. 一方, 採集を行なった岩手県越喜来湾では, レクチ ン量が増加する季節はアカフジッボが最も成長する時期 であるとともに，卵成熟と産卵期にもあたる，確証はな いが，卵成熟への関与も十分考えられる、いずれにせ よ,アカフジッボではリンパ液レクチンは複数の機能を 担って，忙しく立ち働く多機能高分子といらことができ よ5.

最近, 北里大学衛生学部の柴忠義教授らによって, BRA-2 遺伝子は単一エクソンによって構成されている
が，BRA-3 遺伝子は成熟タンパク質をコードする領域 が同じくCタイプ・レクチン・ファミリーの一員である $\mathrm{IgE}$ リセプターのように3つのエクンンによって構成さ れることが明らかにされだ(7). Cタイプ・レクチン遺伝 子構造では機能領域が単一エクンンよりなるものは主に

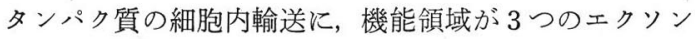
よりなるものは主に異物認識作用に関与していると考壳 られている. 遺伝子構造からも, アカフジッボのマルチ プル・レクチンは互いに異なった生理機能を担っている 可能性があり, その生理機能分担の仕組みはレクチンの 分子進化を考える上でも興味深いものとなろう.

1) 村本光二, 神谷久男: 化学々生物, 28, 631 (1990).

2) K. Muramoto et al.: Comp. Biochem. Physiol., 98 B, 60 (1991).

3) K. Muramoto et al.: Comp. Biochem. Physiol., in press.

4) 羊田達史, 岩永貞炤: 化学之生物, 27, 762 (1989).

5) K. Muramoto et al:: Comp. Biochem. Physiol., in press.

6) M.E.Gunthorpe et al.: Biol. Bull., 179, 191 (1991).

7) N. Takamatsu et al:: Gene, in press.

（神谷久男, 村本光二*, 北里大学水産学部, *現在東北大学農学部)

\section{植物の過酸化水素代謝の比較生化学}

\section{消去系に大きな違い，藻類のもつ活性酸素耐性の光合成 $\mathrm{CO}_{2}$ 固定能に期待}

活性酸素の 1 つである過酸化水素 $\left(\mathrm{H}_{2} \mathrm{O}_{2}\right)$ は, 植物体 内では主にミトコンドリア，ミクロゾーム拈よび葉緑体 の電子伝達系と種々の酸化酵素により生成したスーパー オキシドラジカル $\left(\mathrm{O}_{2}^{-}\right)$の不均化反応を介して生じる. また，ある種の酸化酵素は直接 $\mathrm{H}_{2} \mathrm{O}_{2}$ を生成する. $\mathrm{H}_{2} \mathrm{O}_{2}$ の毒性は他の活性酸素種に比べてそれ流ぐ強くない が，高濃度に存在するとタンパク質などの標的分子が酸 化され障害を生じる.さらに $\mathrm{H}_{2} \mathrm{O}_{2}$ は $\mathrm{O}_{2}^{-}$, 金属イオン とのフェントン反応により, 最も酸化力の強いヒドロキ シルラジカル $(\mathrm{OH} \bullet)$ を生成する. $\mathrm{H}_{2} \mathrm{O}_{2}$ 消去酵素とし て, 動物のグルタチオンペルオキシダーゼ (GSHP) と 植物のアスコルビン酸（AsA） ペルオキシダーゼ（As AP), そしてペルオキシゾームのカタラーゼなどが知ら れている(1,2).

高等植物の AsAP は, 葉緑体のストロマ, チラコイド 膜および細胞質にアイソザイムとして局在している(2,3).
葉緑体ストロマ型 AsAP は, AsA 再還元系のモノデヒ ドロアスコルビン酸 (MDAsA) レダクターゼ (MDAs AR), デヒドロアスコルビン酸レダクターゼ(DAsAR), さらにはグルタチオン (GSH) レダクターゼ (GSHR) と共役し，チラコイド膜で生成する光還元力 (NADPH) を利用して効率的に $\mathrm{H}_{2} \mathrm{O}_{2}$ を消去している(2). 一方，チ ラコイド結合型 AsAP では, 生成する MDAsA を還元 型フェレドキシンが直接還元する(3). 高等植物の葉緑体 は定常状態で $240 \mu \mathrm{M} \cdot \mathrm{s}^{-1}$ の速度で $\mathrm{H}_{2} \mathrm{O}_{2}$ を生成する が, $10 \mu \mathrm{M}$ の $\mathrm{H}_{2} \mathrm{O}_{2}$ は光合成 $\mathrm{CO}_{2}$ 固定能を $50 \%$ 阻害 する. したがって, 高等植物の生命維持のために AsAP による $\mathrm{H}_{2} \mathrm{O}_{2}$ 消去系は必要不可欠な機構である(2). ただ し，高等植物のミトコンドリアで生成する $\mathrm{H}_{2} \mathrm{O}_{2}$ がどの ように消去されるかは, AsAP のアイソザイムやカタラ 一ゼの役割分担も含めて今後の興味ある課題である.

藻類は高等植物と同様の $\mathrm{O}_{2}^{-}$を介した $\mathrm{H}_{2} \mathrm{O}_{2}$ 生成系 


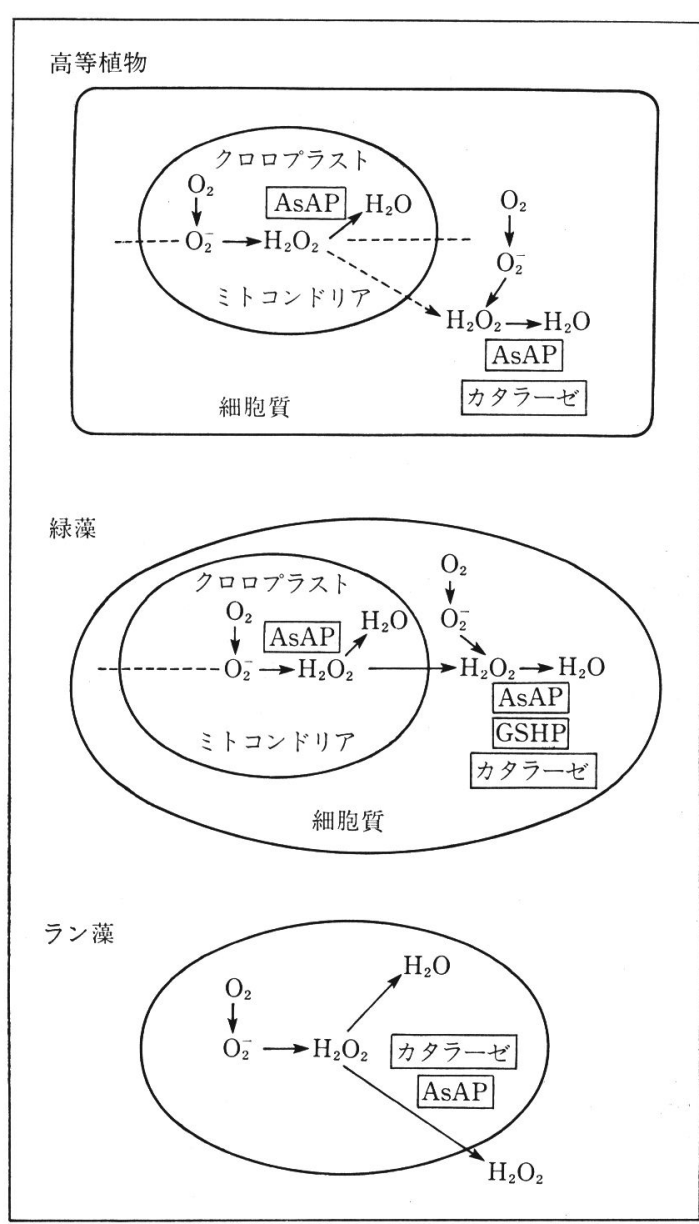

図 1"高等植物, 緑藻およびラン藻における $\mathrm{H}_{2} \mathrm{O}_{2}$ 代謝 $^{(11)}$

を有し，一方 $\mathrm{H}_{2} \mathrm{O}_{2}$ 消去酵素としてペルオキシダーゼお。

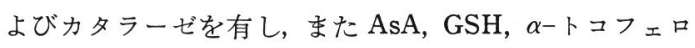
一ルなどの抗酸化剤も多く含んでいる ${ }^{(4,5)}$. 単細胞真核 生物でカタラーゼをもたないニーグレナ (Euglena gracilis Z) は, AsAP 执よびその酸化還元系を唯一の $\mathrm{H}_{2} \mathrm{O}_{2}$ 消去系として発達させ, 葉緑体の光還元力を一部利用し て $\mathrm{H}_{2} \mathrm{O}_{2}$ 除去を行なっている(4,6). 一方, クラミドモナ ス (Chlamydomonas reinhardtii) はカタラーゼと As AP をもつ. ところが, クラミドモナスをセレンを含む 培地で培養すると，既存の AsAP 活性が消失し，新たに GSHP 活性が発現する.この GSHP の酵素学的および 免疫学的性質は動物由来のもの之類似している た，セレン添加による本酵素の誘導には，充分な光強度 $(8,000 \sim 10,000$ lux $)$ と空気レベルの低 $\mathrm{CO}_{2}$ 濃度 $(0.03$
\%) が必要である(8). カタラーゼ活性はセレンの影響を 受けず常に高值を示し, $\mathrm{H}_{2} \mathrm{O}_{2}$ に対する $K_{\mathrm{m}}$ 值 (16.7 $\mathrm{mM}$ ) は動物由来のカタラーゼ $(1.1 \mathrm{M})$ に比べてかな り低い.クラミドモナス葉緑体において, $\mathrm{H}_{2} \mathrm{O}_{2}$ は光合 成偽循環型電子伝達系で $\mathrm{O}_{2}^{-}$を介して $100 \sim 150 \mu \mathrm{mol} /$ $\mathrm{mg}$ クロロフィル/時間の速度で生成される. したがっ て, セレン存在下で培養した細胞では, $\mathrm{H}_{2} \mathrm{O}_{2}$ 消去は主 に GSHP により行なわれる. 一方, セレン非存在下で 培養した細胞では，60\%の $\mathrm{H}_{2} \mathrm{O}_{2}$ がカタラーゼにより， そして残りは AsAP により消去される(8).

ラン藻はカタラーゼを含むが，AsAP はまったく含ま ないか, あるいは含んでもその活性はきわめて低いもの に大別される(6). ラン藻の AsAP も緑藻の場合と同様に 光還元生成物を電子供与体とする. また, Synechococcus 7942 やSynechocystis 6803 のカタラーゼの $\mathrm{H}_{2} \mathrm{O}_{2}$ に対する $K_{\mathrm{m}}$ 值は数 $\mathrm{mM}$ である. したがって, ラン藻 での $\mathrm{H}_{2} \mathrm{O}_{2}$ 消去は, カタラーゼと光還元力を利用したペ ルオキシダーゼ反応により行なわれている. 最近, 高酸 素濃度および強光下のラン藻で, 生成する $\mathrm{H}_{2} \mathrm{O}_{2}$ の一部 が細胞外へ排泄されることも明らかになっている.

ユーグレナの AsAP および AsA 酸化還元系の酵素 は，葉緑体ではなく細胞質画分にのみまたクラミドモ ナスの AsAP は葉緑体に, GSHP は細胞質画分にのみ 局在している. 最近, 緑藻から単離した無傷葉緑体やミ トコンドリアが $\mathrm{H}_{2} \mathrm{O}_{2}$ を生成し，それを速やかにオルガ ネラ外に移行させることが確認された(9). ちなみに, 活 性酸素の中でも, $\mathrm{H}_{2} \mathrm{O}_{2}\left(\mathrm{p} K_{\mathrm{a}}=11.8, \mathrm{H}_{2} \mathrm{O}_{2} \rightarrow \mathrm{H}_{2} \mathrm{O}^{-}+\right.$ $\mathrm{H}^{+}$) は自由に生体膜を通過し細胞全体に拡散できる。

以上述べてきたことを総合すると, 緑藻のオルガネラ で生成される $\mathrm{H}_{2} \mathrm{O}_{2}$ のほとんどは, オルガネラ内で消去 されるのではなく, 膜を通過して細胞質に移行した後, 一連の消去系により除かれるものと考えられる．

藻類の $\mathrm{H}_{2} \mathrm{O}_{2}$ 消去系は高等植物のそれに比べて, 特に 消去系酵素の局在性において大きく異なることを示して きた.この事実と藻類での $\mathrm{H}_{2} \mathrm{O}_{2}$ 生成速度を考え併わせ ると, たとえ $\mathrm{H}_{2} \mathrm{O}_{2}$ がオルガネラ外へ移行したとして も, 瞬時には葉緑体内の $\mathrm{H}_{2} \mathrm{O}_{2}$ 濃度は数 $\mathrm{mM}$ 以上にな る. 前述のよらに, もし高等植物がこのよらな状況下に 置かれると, 光合成 $\mathrm{CO}_{2}$ 固定は直ちに停止する. なぜ, 
瞬時たりとも高濃度の $\mathrm{H}_{2} \mathrm{O}_{2}$ が蓄積されるような環境下 に拈いて藻類は生育可能なのか？筆者らは，この疑問 に対する解答を高等植物と藻類に敃ける光合成 $\mathrm{CO}_{2}$ 固 定の $\mathrm{H}_{2} \mathrm{O}_{2}$ に対する感受性の相違で説明できると推察し た. 事実, ユーグレナ, クラミドモナスおよびラン藻の 光合成 $\mathrm{CO}_{2}$ 固定は, 高等植物のそれに比べて高濃度の $\mathrm{H}_{2} \mathrm{O}_{2}$ に対して耐性を有していた(10). さらに, $\mathrm{CO}_{2}$ 固定 関連のチオール酵素（フルクトース-1, 6-ビスリン酸ホ スファターゼ, $\mathrm{NADP}^{+}$タグリルアルデヒド-3-リン酸 デヒドロゲナーゼおよびリブロース-5-リン酸キナーゼ） は, $1 \mathrm{mM} \mathrm{H} \mathrm{H}_{2}$ 存在下でも活性を保持していた.この ことは, 藻類における光合成能の $\mathrm{H}_{2} \mathrm{O}_{2}$ 耐性機構はチオ 一ル酵素の $\mathrm{H}_{2} \mathrm{O}_{2}$ に対する耐性に依存していることを示 している.

図 1 亿高等植物, 緑藻抄よびラン藻の $\mathrm{H}_{2} \mathrm{O}_{2}$ 代謝を比 較した．藻類にお就る $\mathrm{H}_{2} \mathrm{O}_{2}$ のオルガネラ外への移行括 よび光合成の $\mathrm{H}_{2} \mathrm{O}_{2}$ に対する耐性機構は, ペルオキシダ 一ゼやカタラーゼによる消去系とともに, 細胞内で常に 生成する活性酸素（酸素ストレス）の防御系として進化 過程に㧤いて獲得されたものであると考兄られる(11).

近年, 急速な環境変化に伴らストレスへの植物の対応 機構の解明と, それらへの耐性の強化が注目されてい る. AsAP を中心とする $\mathrm{H}_{2} \mathrm{O}_{2}$ 消去系の環境ストレスへ の応答の解明も進行中であるが(12), 詳細な分子レベルで
の発現・調節機構はまだ明確にされていない、また，活 性酸素消去系の酵素 (SOD, GSHR など) 遺伝子導入に よるトランスジェニック植物の作出も試みられてい $る^{(13,14)}$. これらの植物に, 藻類の活性酸素耐性酵素遺伝 子を付与することは，より強固なストレス耐性植物の開 発につながるものと期待される.

1) 重岡 成: 活性酸素・フリーラジカル，2，38 (1991).

2) K. Asada : Physiol. Plant., 85, 235 (1992).

3) C. Miyake \& K. Asada : Plant Cell Physiol., 33, 541 (1992).

4) 重岡 成：農化誌，66，1739 (1992).

5) S. Shigeoka, H. Ishiko, Y. Nakano \& T. Mitsunaga : Biochim. Biophys. Acta, 1128, 220 (1992).

6) C. Miyake, F. Michihata \& K. Asada : Plant Cell Physiol., 32, 33 (1991).

7) S. Shigeoka, T. Takeda \& T. Hanaoka: Biochem. J., 275, 623 (1991).

8) T. Takeda, Y. Nakano \& S. Shigeoka : Plant Sci., in press (1993).

9) T. Ishikawa, T. Takeda, S. Shigeoka, O. Hirayama \& T. Mitsunaga : Phytochemistry, 33, 1297 (1993).

10) T. Takeda, S. Shigeoka \& A. Yokota: Cur. Res. Photosynth., 3, 741 (1992).

11）重岡 成: 植物細胞工学, 5(6), 15 (1993).

12) R. Mittler \& B. A.Zilinskas : J. Biol. Chem., 267, 21802 (1992).

13) M. Aono, A. Kubo, H. Saji, K. Tanaka \& N. Kondo : Plant Cell Physiol., 34, 129 (1993).

14) C. Bowler, M. V. Montagu \& D. Inze : Annu. Rev. Plant Physiol. Plant Mol. Biol., 43, 83 (1992).

(武田 徹, 重岡 成, 近畿大学農学部)

\section{農法を変革するコーティング肥料}

\section{必要なときに必要なだけ効果を発現。省資源・低公害の新旗手となるか?}

今日広く使用されている速効性肥料は，利用効率が低 く, 肥効も長続きしない。このような速効性肥料の欠点 を克服するために, 1950 年代から速効性肥料をコーテ ィングし，肥料の溶出を緩やかにする研究が始められ た．そして，これまで数多くのコーティング肥料が開発 されているが，そのなかで最も正確な 溶出を示す肥料 一一肥効調節肥料 (CAF) は, 我が国で開発されたポリ オレフィンコート肥料 (POCF) である(1,2). 新しい資材 あるいは機器の発明は，乙ばしば技術革新のきっかけと なる，高性能の CAF は，施肥法だけでなく，農業のシ ステムすなわち農法の变革にも貢献し，これがさらに資
源の節約や環境保全にも貢献することが期待される。

コーティング肥料は，コーティング資材によって硫黄 コートと樹脂コートに分けられ, 後者は, さらに熱硬化 性と熱可塑性に分汀られる.POCF は藤田ら ${ }^{(1,2)}$ によっ て発明された熱可塑性コーティング肥料である. 彼ら は, 肥料成分の溶出を自由に調節するために, 透湿度の 低いポリオレフィン系樹脂に透湿度の高いェチレンビニ ール酶酸をブレンドした．次に，肥料成分の溶出速度の 温度依存性を, 植物の生理活性のそれ $\left(Q_{10}=2\right)$ と一致 させるために, 微細な板状のタルク鉱物を樹脂に添加し た（タルク表面にできる空気膜を水分が通過すること 
表 1 - 代表的な POCF (普通溶出グループ) ${ }^{(2)}$

\begin{tabular}{llll}
\hline 国内の商品名 & タイプ & 化学組成 & 含量 $(\%)$ \\
\hline LP 30 180 & $30,40,50$ & $\mathrm{CO}\left(\mathrm{NH}_{2}\right)_{2}$ & $\mathrm{~N}=40$ \\
(チッツ, & & \\
1980年登録) & $70,140,180$ & & \\
Long 424 & $40,70,100$ & $\mathrm{NH}_{4} \mathrm{NO}_{3}$ & $\mathrm{~N}=14$ \\
(迏化成, & $140,180,270$ & $\left(\begin{array}{l}\mathrm{K}_{2} \mathrm{SO}_{4} \\
\mathrm{NH}_{4} \mathrm{H}_{2} \mathrm{PO}_{4}\end{array}\right.$ & $\begin{array}{l}\mathrm{P}_{5}=12 \\
\mathrm{~K}_{2} \mathrm{O}=14\end{array}$ \\
\hline
\end{tabular}

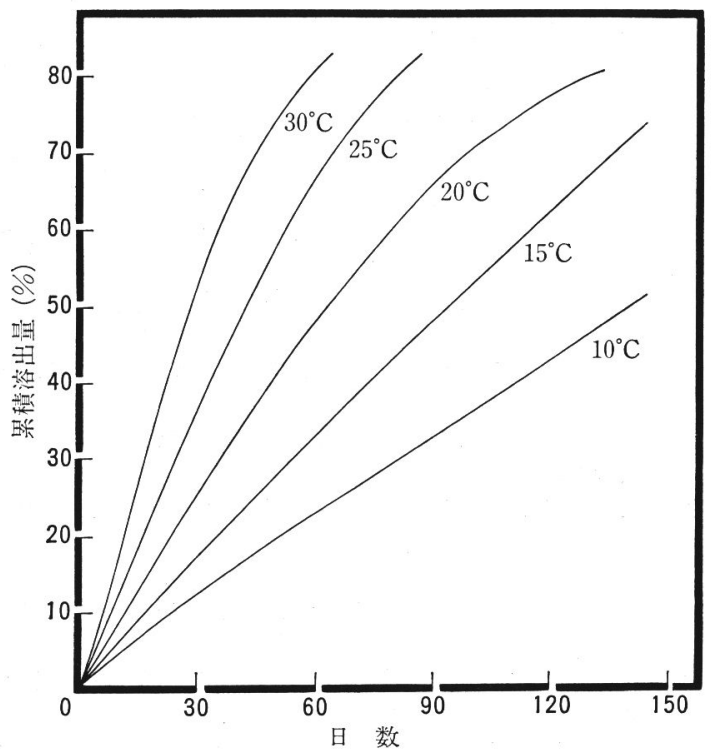

図 1"ポリオレフィンコート尿素における温度と溶出速度との 関係

で， $Q_{10}$ を低下させることができる).

速効性肥料の種類とコーティング材料によって, 多く の種類の POCF が製造販売されているが，その一部を 表 1 に示した. POCF は, 施肥後直ちに溶出を始める普 通溶出グループと, 施肥後一定期間経過したあと溶出を 始める時限式グループに大別される. 各 POCF は, 25 ${ }^{\circ} \mathrm{C}$ で肥料成分の $80 \%$ が溶出する期間をもってタイプと 命名されている. 今日販売されている POCF には, 30 タイプから 360 タイプまである.

必要なとき必要なだけ効果を現わす POCF の優れた 能力は, その溶出過程が土壌温度により正確に決定さ れ, 温度以外の土裹要因にはほとんど影響を受けないこ とにある. いま単成分系のコーティング尿素の溶出と温 度との関係を図 1 に示す. 尿素の溶出は, 低温 (10～15 $\left.{ }^{\circ} \mathrm{C}\right)$ の場合は直線的溶出を, 高温 $\left(20^{\circ} \mathrm{C}\right.$ 以上) の場合に は直線的溶出と曲線的溶出よりなる. 直線部は, 尿素の
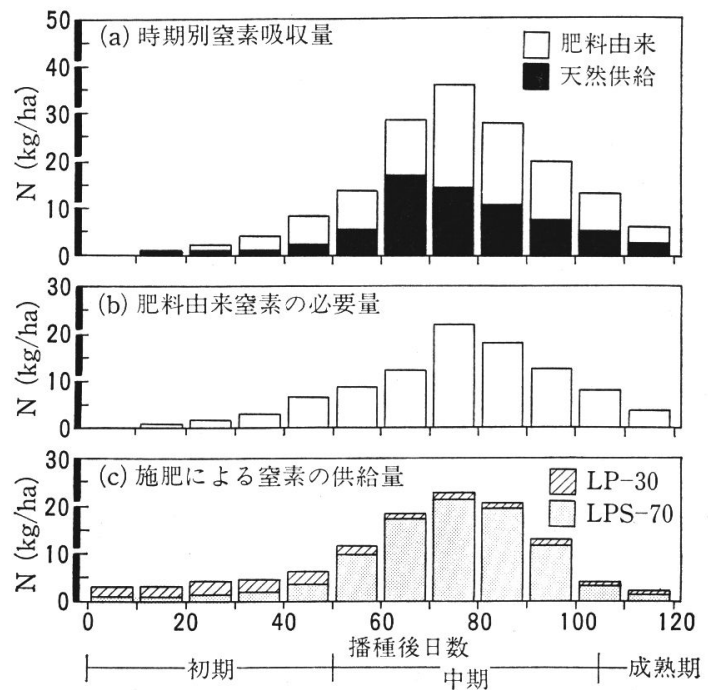

図 2・必要なときに必要な窒素量をトウモロコシへ供給する施 肥 (東北大附属農場)

（a）子実収量 $6 \mathrm{t} / \mathrm{ha}$ を得るために必要な時期別の窒素吸収量, （b）天然供給の不足分を補給するための窒素必要量，（c）初 期生育のための LP-30 (20 kgN/ha) と中後期の生育のための LPS-70 (100 kgN/ha) をブレンドして全量基肥として接触施 肥. (Shoji et al., 1991; チッソ肥料研究所, 1993)

飽和溶出を示し，曲線部は徐々に薄まる不飽和溶出を示 している. 複数成分のコーティング肥料では, 肥料成分 から生成する数種のイオンペアの溶解度によって溶出パ ターンが決定される.この溶出パターンは二次曲線で近 似される。

肥料が必要なときに必要なだけ肥効を発揮するために は，植物根へより直接的に肥料成分を供給することが望 ましい. しかし一般の速効性肥料は，急激に溶解するた めに, 植物は濃度障害をひき起こす。これに対して, 緩 やかに溶解する POCF では, 濃度障害の恐れが小さい ので，接触施肥が可能となる，接触施肥法は，肥料の利 用効率を高めるとともに，農作業の省力化にも役立つこ とになる，ここでは，以下に，POCF が必要なときに必 要なだけの肥効を発揮するために，具体的にどのように 施肥すべきかを，作物の生育収量を最も強く支配するチ ッソを選んで説明しよう。

POCF の接触施肥は, 基本的に一般の速効性肥料の施 肥と同じように，作物の目標収量に必要な養分吸収量の らら，天然供給で足りない分を補給することにある．図 2 の（a）には、トウモロコシの子実収量 $6 \mathrm{t} /$ ha を得る 
ための吸収とその中の天然供給分を，(b) には不足分 を示した.（c）には，その不足分を補給するための施肥 を示した. 初期生育のためには POC 尿素の 30 タイプ (LP-30) を, 中後期の生育のためには時限式の POC 尿 素の 70 タイプ (LPS-70) を用いた. これら 2 種の肥料 の配合と接触施肥によって, 植物の要求に見合った養分 供給ができ，肥料の利用効率を著しく高めることができ る（利用効率は初期が $60 \%$, 中後期が $80 \%$ として計算 した). したがって速効性肥料を施肥する場合に比べて, 施肥量をかなり減らすことができる.

CAF の利用によって, 施肥位置だけでなく, 施肥時 期も大きく変えることができるようになった．たとえ ば, 従来基肥と数回の追肥を行なっていたものを, 全肥 料をまとめて基肥として施肥できたり， 1 年 2 作の栽培 のために, 溶出タイプの異なる $\mathrm{CAF}$ を配合して, 1 回 に施肥することもできる. さらに花卉園芸植物では, 興 味ある施肥法もいろいろと考案されている.

CAF の利用によって, 施肥法から農法の変革も現実 的となってきた. たと吝ば東北地方では, 水稲の必要と
する肥料をすべて CAF を使って育苗箱に施肥する方法 が試みられている（肥料粒子は水稲根によってだきかか えられて，田植によって臣とえどすべて水田に持ら込ま れる)。このような苗を耕起しない水田に移植できるよ らになれば，その経済効果は大きいだろう。

CAF は，一般の速効性肥料に比べて作物による高い 利用効率を示寸. このために, 施肥量が節減でき, これ が肥料資源やこれを製造するための化石エネルギーの節 減に役立つ. また，CAFによる利用効率の向上は，今日 多肥農業で深刻化している肥料公害の軽減に貢献するで あろう. そして, 農法の変革一一不耕起全肥料基肥栽培 の確立は, 農業機峨の負担を軽くし, 土畩侵食を防止 し，環境保全にも役立つであろう．かくして CAF は， 今日成熟産業といわれる肥料産業を再生させ, 新たな施 肥農業を発展させるきっかけとなるかも知れない。

1) 藤田利雄ら：肥料の現状と将来, 111 (1989).

2) S. Shoji \& A. T. Gandeza : "Controlled Release Fertilizers with Polyolefin Resin Coating”, 今野印刷, 1992.

(庄子貞雄, 東北大学農学部)

\section{理化学研究所研究員}

本研究所生体物理化学研究室ではへム蛋白質の構造と機能に 関する研究を蛋白質レベル，細胞レベルで行なっています．今 回は「遺伝子工学的手法による蛋白質の発現および変異蛋白質 の構造と機能関する研究」に與味を招持らで柔軟性のある若 手研究者 (32歳以下が望ましい) を求めています.

提出書類 : (1)履歴書 (写真貼付), (2)研究業績目録および 主要
論文の別刷各 1 部, (3)従来の研究内容と今後の研究に対する 抱負 (800字前後で), (4)推薦書 (自薦の場合は不要) 応募締切日: 平成 6 年 1 月15日

送付先・問合せ先 : T351-01 埼玉県和光市広沢 2-1 理化学研究所·生体物理化学研究室 飯塚哲太郎 Tel. 048-462-1111 (内 5461), Fax. 048-462-4660 (直通) 